\title{
Comparative feeding ecology and habitats use of Crenicichla species (Perciformes: Cichlidae) in a Venezuelan floodplain river
}

\author{
Carmen G. Montaña and Kirk O. Winemiller
}

Feeding behavior and habitat use of two species of pike cichlids, or mataguaros, (Crenicichla lugubris and C. aff. wallacii) were studied in the río Cinaruco, a floodplain river in the Venezuelan llanos. We examined 309 individuals of C. lugubris and 270 individuals of $C$. aff. wallacii from both the main channel and lagoons throughout the falling-water phase of the annual hydrological cycle. Crenicichla lugubris was common within habitats that contained rocks or woody debris, whereas $C$. aff. wallacii was more abundant in lagoons than the main channel, especially within shallow areas containing leaf litter. Although we did not capture $C$. aff. wallacii in rocky shoals, they sometimes were observed in these habitats. Crenicichla lugubris was larger than C. aff. wallacii (198.4 mm and $44.6 \mathrm{~mm}$, respectively). Analysis of stomach contents showed that larger specimens (> $100 \mathrm{~mm}$ SL) C. lugubris fed mostly on small fishes (e.g. characids, cichlids), but juveniles ( $<100 \mathrm{~mm} \mathrm{SL}$ ) consumed mostly aquatic insects, fish scales, and shrimps. Crenicichla aff. wallacii fed on aquatic insects and other invertebrates associated with leaf litter substrates.

O comportamento alimentar e o uso de habitat de duas espécies de “joanas”, ou "mataguaros”, (Crenicichla lugubris e C. aff. wallacii) foram estudados no río Cinaruco, uma planície de alagamento nos llanos Venezuelanos. Examinamos 309 indivíduos de $C$. lugubris e 270 de $C$. aff. wallacii do canal principal e lagoas ao longo da fase de vazante de um ciclo hidrológico anual. Crenicichla lugubris foi comum em ambientes que continham rochas, galhos e troncos, enquanto que $C$. aff. wallacii foi mais abundante em lagoas do que no canal principal, especialmente em áreas rasas contendo folhiço. Embora não tenhamos capturado C. aff. wallacii em cardumes em meio às rochas, em algumas ocasiões eles foram observados nestes ambientes. Crenicichla lugubris foi maior do que C. aff. wallacii (198,4 mm e 44,6 mm CP, respectivamente). Análise dos conteúdos estomacais de $C$. lugubris revelou que os indivíduos maiores ( $>100 \mathrm{~mm} C P$ ) se alimentaram principalmente de peixes pequenos (e.g. caracídeos e ciclídeos), e os menores (<100 mm CP) consumiram principalmente larvas aquáticas de insetos, escamas de peixes e camarões. Crenicichla aff. wallacii se alimentou de insetos aquáticos e outros invertebrados associados ao folhiço.

Key words: Llanos, Pike cichlid, Neotropics, Niche breadth, Venezuela.

\section{Introduction}

With 83 described species (Eschmeyer \& Fricke, 2009), the genus Crenicichla (Heckel, 1840) is the second largest genus of South American cichlids following Apistogramma (Kullander, 2003; Kullander \& Lucena, 2006; Lucena, 2007). Crenicichla species, referred to as pike cichlids in English and 'mataguaros' in Venezuela and other South America countries, are distributed across regions north of the Amazon River, including Venezuela, Colombia and Guyana, throughout the Amazon basin, and within Atlantic basins to central Argentina in the south (Kullander, 2003). All Crenicichla have elongate bodies and protrusible jaws characteristic of many predatory fish. Like other cichlids, Crenicichla species have well developed brood- defense behavior and display a high degree of aggression toward conspecifics (Barlow, 2000). Most information about reproduction and parental care of Crenicichla species has been produced by aquarium hobbyists (Leibel, 1992; Bethea, 2007), however, few scientific data for Crenicichla species in natural systems have been published. Kullander (1990,1991), Kullander \& Lucena (2006), and Lucena (2007) reported information about habitat and diet for eight Brazilian species. Knöppel (1970) reported food habits in a study of the fishes of Central Amazonas, and Lowe-McConnell (1969) reported on the ecology of fishes in Guyana; all of them found that Crenicichla species feed mostly on fish and aquatic insects. Similarly, Gibran et al. (2001) found that $C$. britskii from the upper rio Paraná was a generalist invertivore, feeding mostly on immature forms

Section of Ecology, Evolution and Systematic Biology, Department of Wildlife \& Fisheries Sciences. Texas A\&M University, College Station, TX 77843-2258, USA. car1607@tamu.edu (CGM), k-winemiller@tamu.edu (KOM) 
of aquatic insects and crustaceans.

In tropical floodplain rivers, strongly seasonal variation in hydrology is known to play an important role in determining habitat quality and resource availability for fishes (LoweMcConnell, 1987). During the wet season, more food becomes available and fishes scattered in the flooded savannas and forests, but during the dry season, reduction of water volume reduces habitat and increases fish densities which results in more intense species interactions (Winemiller, 1989; Winemiller \& Jepsen, 1998). As food resources become scarce, interspecific dietary overlap generally decreases, a pattern consistent with resource partitioning (Lowe-McConnell, 1987). For example, piscivorous peacock cichlids (Cichla spp.) in a floodplain river of the Venezuelan llanos demonstrate greater dietary overlap during the annual rising and falling water periods relative to the low-water period (Jepsen et al., 1997; Hoeinghaus et al., 2007; Montaña et al., 2007). Jepsen et al. (1997) found that three Cichla species inhabiting the Cinaruco River partitioning both food and habitat, especially during the dry season. Average dietary overlap among nine piscivores fishes was lowest during the dry season in a creek of the Venezuelan llanos (Winemiller, 1989). Piscivorous cichlids (Serranochromis spp.) of the Upper Zambezi River (Africa) revealed stronger patterns of resource partitioning and niche complementarity when the water level was descending (Winemiller, 1991), and similar patterns of habitat use and dietary overlap were observed for tilapiine cichlids of the upper Zambezi (Winemiller \& Kelso-Winemiller, 2003).
In the present study we examine diet and habitat use for two sympatric species of Crenicichla from Cinaruco River, a floodplain river in the Venezuelan llanos (savanna region): Crenicichla lugubris Heckel, 1840 and C. aff. wallacii Regan, 1905 (Fig. 1). The analysis focuses on dietary variation associated with ontogeny and patterns of habitat use during the dry season period.

\section{Material and Methods}

Study area. This study was conducted in the Cinaruco River, a moderate blackwater river in the Venezuelan llanos, Apure State (Fig. 2). The Cinaruco is characterized by a low-gradient, sandy oligotrophic substrates, and high fish diversity (> 280 fish species) that spans a wide range of ecological attributes and life history strategies (Layman et al., 2005; Willis et al., 2005). The Cinaruco River has a strongly seasonal hydrology with a pronounced annual wet and dry season (Montoya et al., 2006). During the wet season (May to October), the riparian forest and surrounding savanna is flooded, and organisms disperse widely throughout the river floodplain. The dry season is associated with a continuously falling water level that forces aquatic organisms off the floodplain and into the main river channel and lagoons (Winemiller \& Jepsen, 1998; Arrington et al., 2005).

Three macrohabitats are common in the Cinaruco River: tributary creeks, floodplain lagoons, and the main river channel. The main river channel contains long, broad sand banks that

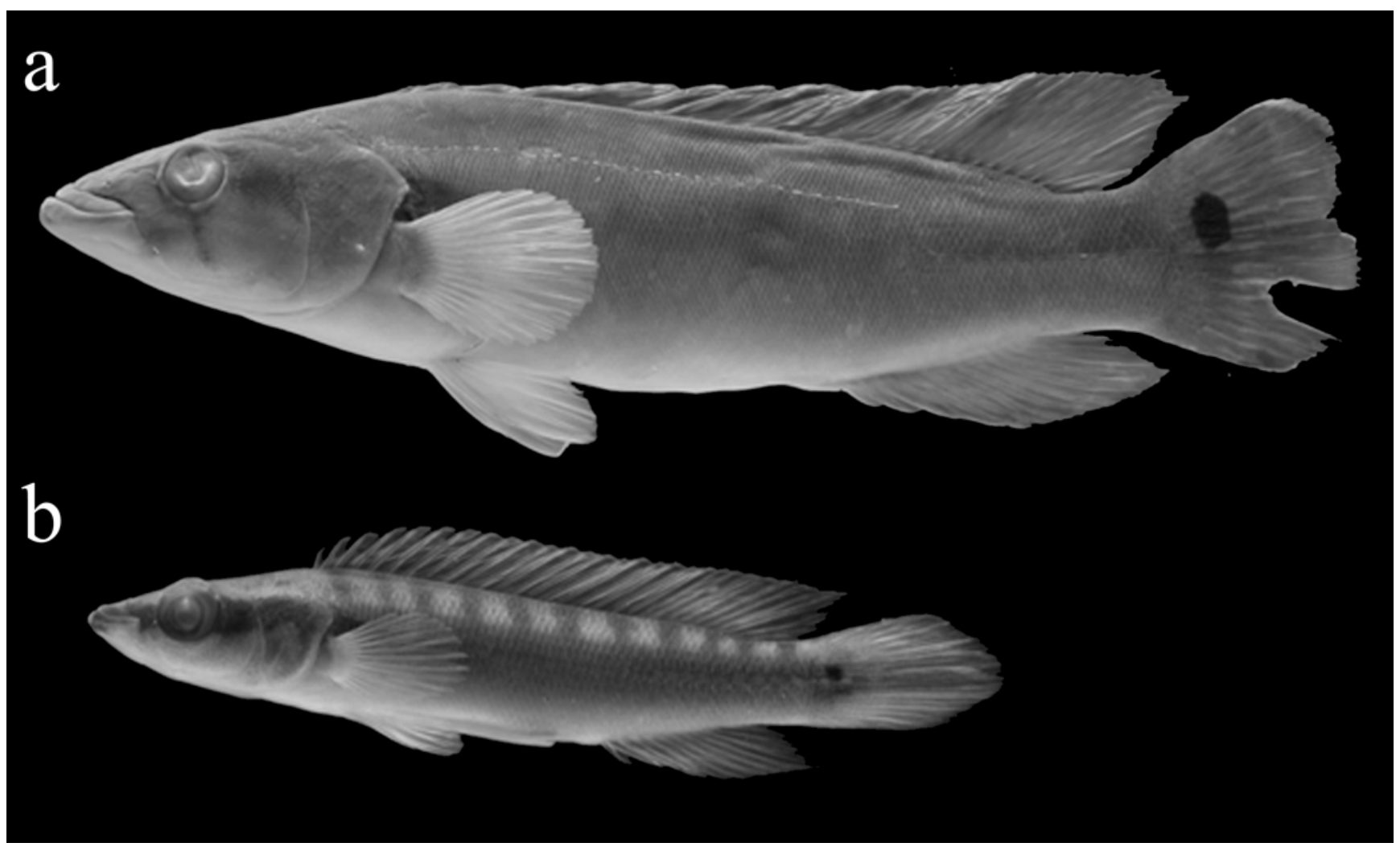

Fig. 1. Specimens of (a) Crenicichla lugubris (217 mm SL) and (b) C. aff. wallacii (51 mm SL) from the Cinaruco River, Venezuela. 
constitute a large portion of the river shoreline during the dry season. Small rocky patches and submerged branches and tree trunks become important shoreline habitats in the main channel during the dry season when the water level drops as much as 7 $\mathrm{m}$. Many floodplain lagoons have permanent surface-water connections to the main channel during the dry season; but others become isolated water bodies. Meandering creeks fringed by gallery forest drain the floodplain into the main channel and lagoons. Lagoons and creeks have more heterogeneous habitats in comparison to the main river channel, including patches of sand banks, leaf litter, submerged vegetation, and rocks (Arrington \& Winemiller, 2006).

Sampling methodology. Sampling was conducted during the dry season from December 13, 2005 to May 82006 (Fig. 3). No surveys were conducted during January 2006. We collected Crenicichla lugubris and C. aff. wallacii from river channel, lagoons, and creeks. Within those three macrohabitats, four habitats were sampled: leaf litter, sand banks, submerged vegetation, and rocky patches. Collections were conducted only during day hours. Although most collections were made at morning (8:00-11:00 am) or afternoon (12:00-5:00 pm) we did the dietary analyses to time of month instead of to time of day.

On sand banks and leaf litter substrates, fish were sampled with a seine (6.4 x $1.8 \mathrm{~m}, 4-\mathrm{mm}$ mesh). In unstructured sand banks, seine hauls were initiated from a depth that usually was between $0.3-1.0 \mathrm{~m}$ and terminated at the shoreline. At each collection site, samples consisted of three hauls that were non-overlapping in the area covered (following method of Layman \& Winemiller, 2004).

In locations with submerged woody debris and rocky patches, fish were captured with hooks (\# 8) baited with a small piece of fish flesh. Fish were captured with two techniques; therefore catch-per-unit-effort (CPUE) data are not comparable between methods. Abundance was recorded as CPUE based on the method - the number of individuals collected with hooks per hour, or the number of individuals captured per meter of seine haul. Fishes were preserved in $10 \%$ formalin in the field, and specimens were later counted and examined in the laboratory. Voucher specimens are archived in the Museo de Ciencias Naturales at UNELLEZ Guanare, Venezuela. The lot of references examined in the Museo de Ciencias Naturales - Guanare for each species were: Crenicichla lugubris: MCNG - 47358 to MCNG - 55140, Crenicichla aff. wallacii: MCNG - 45574 to MCNG - 53130.

The standard length (SL) of each specimen was recorded to the nearest $0.1 \mathrm{~mm}$ using vernier calipers or a plastic ruler. Whenever available, 15 or more specimens of each species of Crenicichla were examined for each month (December to May, excluding January) for stomach contents. Gonad state was examined (following Nikolsky, 1963) for a size-representative to determine size of maturation of both species of Crenicichla. Stomachs were removed from the specimens, and all food items were removed from each and spread on a glass dish for examination under a microscope. For stomach contents

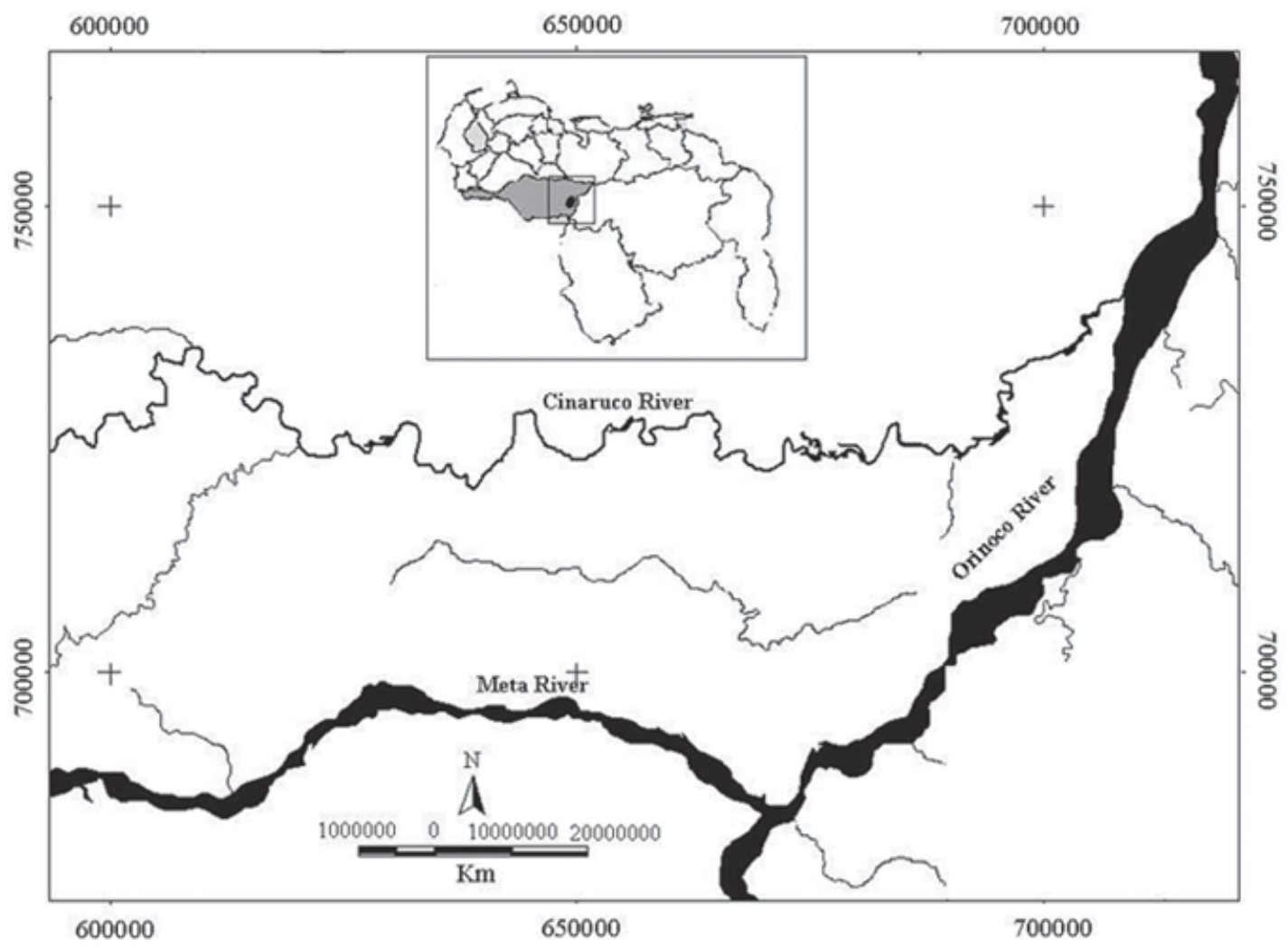

Fig. 2. Map showing location of the Cinaruco River, a tributary of the Orinoco River in Venezuela's Apure State; the study reach is outlined with a rectangle. 
analysis, we followed Winemiller's (1990) methods of microscopic examination and gut volumetric estimation. Prey items were identified to the lowest feasible taxonomic level using keys for aquatic invertebrates (Pennak, 1978) and fishes (multiple literature sources). Diet items were aggregated into taxonomic orders for use in calculation of dietary breadth and diet similarities (see Adite \& Winemiller, 1997 for details). Aquatic insects were grouped as Diptera (e.g. Chironomid larvae), Hemiptera (e.g. Naucoridae), Collembolla, Odonata, Ephemeroptera, and Coleoptera. Crustacea were recorded as Decapoda, Copepoda, Ostracoda or Cladocera. Annelida were recorded as Oligochaeta or Hirudinea. Fishes from stomachs were identified to genus and species whenever possible. The other fish diet category was unidentified fish, which included fish scales, fish bones, fish eggs, and fish fins. Diet diversity was estimated using Levins' (1968) index of niche breadth (also called niche width or niche size):

$$
\mathrm{B}^{\prime}=\left(\sum_{\mathrm{i}=1}^{n} P_{i}^{2}\right)^{-1}
$$

where B' is niche breadth, $P i$ is the volumetric proportion of food item $i$ in the diet, and $\mathrm{n}$ is the total number of food items in the diet. Diet similarities were calculated using Pianka's (1973) symmetrical measure of niche overlap:

$$
\theta_{j k}=\left(\sum_{i=1}^{n} P_{i j} * P_{i k}\right) /\left(\sum_{i=1}^{n} P_{i j}{ }^{2 *} P_{i k}{ }^{2}\right)^{1 / 2}
$$

where $\theta_{j k}$ is symmetrical niche overlap between species $j$ and $k, P_{i j}$ is the proportion of the resource $i$ used by species $j$, and $P_{i k}$ is the proportion of resource $i$ used by species $k$, and $n$ is the total number of resources categories. Diet data were compiled and analyzed using Excel Microsoft 2000.

\section{Results}

Habitat use and population size structure. A total of 245 samples was collected from three habitat types in the Cinaruco River during this study. Six hundred twenty five specimens of Crenicichla aff. wallacii and 60 individuals of $C$. lugubris were collected with the seine, and 309 C. lugubris and 16 C. aff. wallacii were collected with hooks with a total effort of 155.9 hours. Most C. lugubris and C. aff. wallacii were captured in lagoons (230 and 439 with hooks and the seine, respectively). Crenicichla lugubris was captured efficiently with hooks in rocky and woody debris habitats, whereas seining was the most efficient technique to capture $C$. aff. wallacii on sand banks and leaf litter habitats. We did not capture $C$. aff. wallacii from rocky patches or submerged woody debris, however, we observed several specimens of this species in both mesohabitats.

Total number of individuals examined for stomach contents were 309 C. lugubris (58\% lagoon, 19\% creek, and
23\% channel) and 270 C. aff. wallacii (48\% lagoon, 34\% channel, and $18 \%$ creek). Relatively large size classes of $C$. lugubris were captured during the study (mean SL $=198.4$ $\mathrm{mm}, \mathrm{SD}=47.2$ ), whereas all $C$. aff. wallacii sizes were less than $70 \mathrm{~mm} \mathrm{SL}$ (mean $=44.6 \mathrm{~mm}, \mathrm{SD}=6.67$ ).

Size intervals were used to estimate size of sexual maturation for both species of Crenicichla following Nikolsky (1963) criteria. Most C. lugubris below $190 \mathrm{~mm}$ were found with unripe gonads (gonad state 1-2) (Fig. 4), whereas most individuals with ripe gonads (gonads state above 3 ) were found within intervals above $190 \mathrm{~mm}$. In C. aff. wallacii, most individuals examined showed unripe gonads below $50 \mathrm{~mm}$ (Fig. 4), only few individuals above $51 \mathrm{~mm}$ were found with ripe gonads. These findings suggest that $C$. lugubris and $C$. aff. wallacii from Cinaruco River reach their sizes of maturation above $190 \mathrm{~mm}$ and $150 \mathrm{~mm}$ SL, respectively.

Crenicichla lugubris was captured more frequently during the dry season (December-March) than the beginning of the rainy season (April-May). When the water level was rising during the last two weeks of April and part of May, we did not collect $C$. lugubris either from rocks or woody debris, even though we saw individuals swimming in these habitats. In tropical freshwater rivers, the period of lower water is known to increase fish density per unit surface area (Lowe-McConnell, 1987). Even though this study did not show information about the whole cichlid assemblages in Cinaruco River, we were able to record at least other 12 cichlids sharing the same habitat with C. lugubris. During the dry season, predators including those within of Cichlidae family are known to increase their foraging activity (Jepsen et al., 1997; Hoeinghaus et al., 2006). Our findings with $C$. lugubris seem quite related with the previous studies showing the effects of seasonality on fish dynamic (Lowe-McConnell, 1987; Winemiller \& Jepsen, 1998).

Feeding habits. Crenicichla lugubris $<100 \mathrm{~mm}$ SL consumed mostly benthic aquatic insects, especially immature stages of Diptera (Chironomidae), Ephemeroptera, Coleoptera, Odonata, and Hemiptera. Crenicichla lugubris > $101 \mathrm{~mm}$ SL consumed mostly fish. Six fish families were identified as food items: small fishes belonging to the Characidae (Hemigrammus sp.,

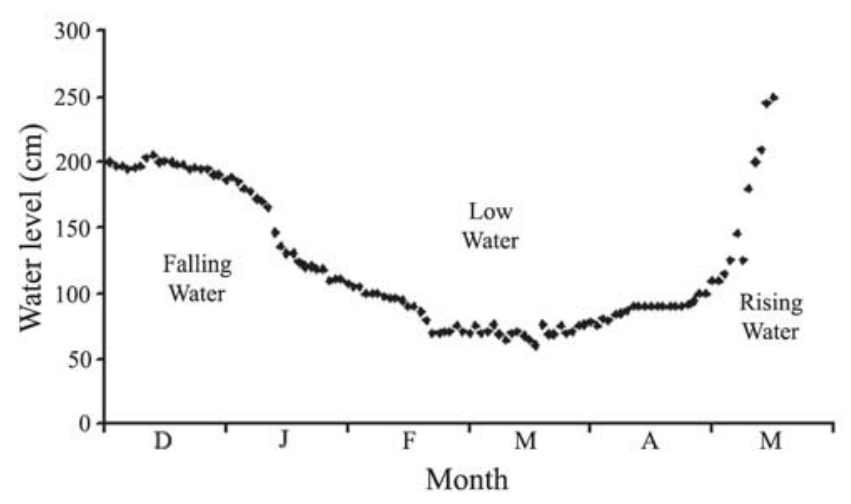

Fig. 3. Water level fluctuations of the Cinaruco River from December 13, 2005 to May 8, 2006. 


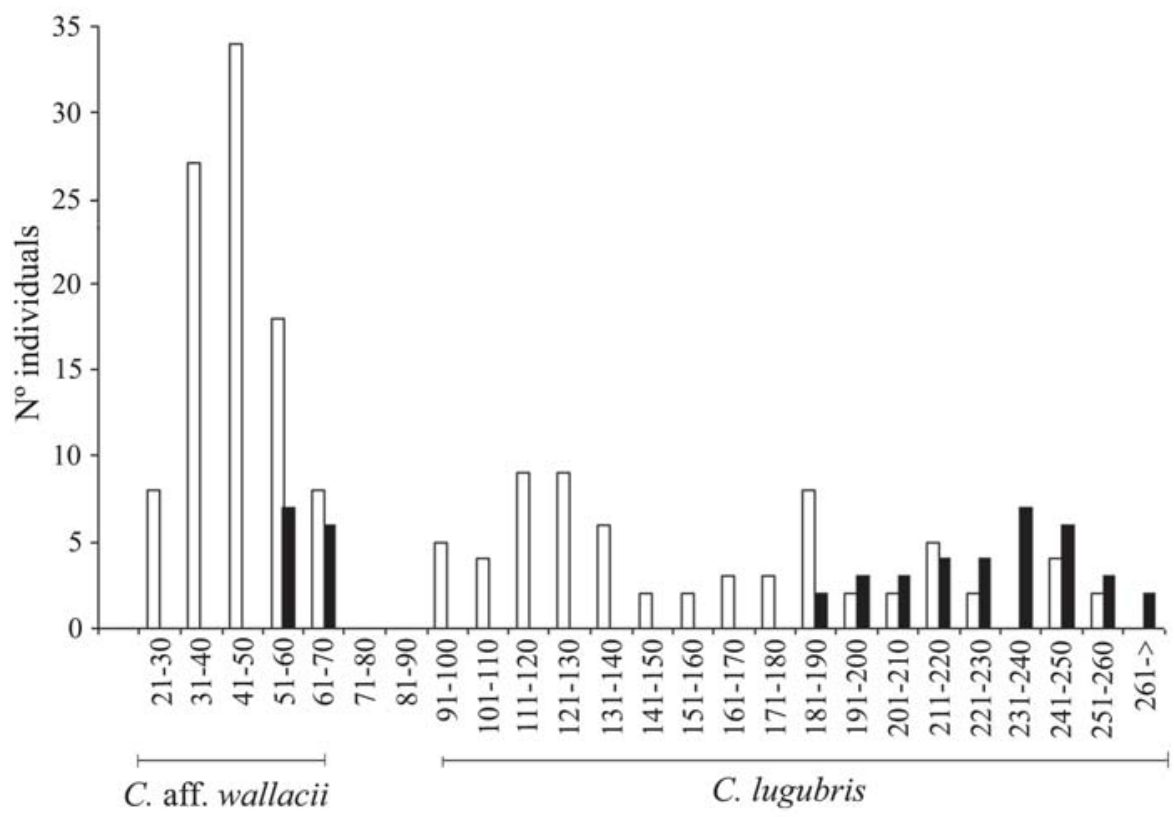

Fig. 4. Number of immature and mature gonads encountered in C. lugubris (a) and C. aff. wallacii (b) of different size classes during the dry season. (black barra) Mature (gonad state > 3); (white barra) immature (gonad state 1-2). C. lugubris $(\mathrm{n}=102)$, C. aff. wallacii $(\mathrm{n}=108)$.

Moenkhausia copei, Bryconops sp.) and Cichlidae (Apistogramma sp.) were dominant (by volume) in the diets of individuals between 101-200 mm, followed by Anostomidae, Doradidae, unidentified fish parts, and Crustacea (Decapoda primarily) (Table 1). Comparison of volumetric proportions consumed by juvenile $(<100 \mathrm{~mm}$ SL) and adult size classes $(>$
$101 \mathrm{~mm}$ SL) indicated diet shifts. Diet breadth (B') for fish from the three mesohabitat types was low for all size classes of $C$. lugubris. Mean $( \pm \mathrm{SD})$ of diet breadth was $0.33( \pm 0.01)$ for lagoons, $0.22( \pm 0.01)$ for creeks, and $0.16( \pm 0.02)$ for the channel. Diet overlap among the three different size classes of conspecifics in the three habitat types was low: $\theta_{j k}=0.10$ for

Table 1. Volumetric percentages of dominant food resource categories consumed by size classes of $C$. lugubris in three habitats of Cinaruco River. Number of stomachs with prey items: Lagoon ( $n=35)$, creek $(n=17)$, Channel $(n=22)$.

\begin{tabular}{|c|c|c|c|c|c|c|c|c|c|}
\hline \multirow{2}{*}{ Items } & \multicolumn{3}{|c|}{ Lagoon } & \multicolumn{3}{|c|}{ Creek } & \multicolumn{3}{|c|}{ Channel } \\
\hline & $<100 \mathrm{~mm}$ & $101-200 \mathrm{~mm}$ & $201-300 \mathrm{~mm}$ & $<100 \mathrm{~mm}$ & $101-200 \mathrm{~mm}$ & $201-300 \mathrm{~mm}$ & $<100 \mathrm{~mm}$ & $101-200 \mathrm{~mm}$ & $201-300 \mathrm{~mm}$ \\
\hline Unident. terr. insect & & 3.78 & 1.73 & & & & & & \\
\hline Unident. aq. insect & 17.86 & 0.63 & 0.69 & 1.41 & 1.08 & & & & 0.30 \\
\hline Aquatic insect eggs & & 0.95 & & & & & & & \\
\hline Coleoptera & & & 0.43 & & 10.85 & 3.51 & & & \\
\hline Ephemeroptera & & 1.26 & & 1.41 & & 0.35 & & 0.53 & \\
\hline Hemiptera & & 0.63 & & 9.86 & 2.17 & 10.54 & & & \\
\hline Naucoridae & 80.36 & & 0.09 & 28.17 & & & & & \\
\hline Odonata & & 0.32 & & & 5.42 & 3.51 & & & 12.03 \\
\hline Diptera & & & & 2.82 & 0.54 & & & & \\
\hline Hirudinea & & 0.06 & & & & & & & \\
\hline Nematoda & 0.89 & & & 42.25 & 0.54 & & & & \\
\hline Oligochaeta & & & 0.35 & & & & & & \\
\hline Decapoda & & 12.00 & 17.30 & & 10.85 & 3.51 & & 21.39 & 2.41 \\
\hline Characidae & & & 22.44 & & 37.96 & 11.07 & & 74.87 & 12.63 \\
\hline Cichlidae & & 18.90 & & & & 14.06 & & & 16.24 \\
\hline Doradidae & & 13.86 & 4.32 & & & & & & \\
\hline Anostomidae & & 12.60 & & & & & & & 36.09 \\
\hline Synbranchidae & & 7.56 & & & & & & & \\
\hline Heptapteridae & & 0.63 & & & & & & & 3.61 \\
\hline Fish eggs & & & 0.43 & & & & & & \\
\hline Unident. fish & & 21.16 & 12.95 & & 10.85 & & & & 13.83 \\
\hline Fish bone & & 1.76 & 15.36 & & 0.54 & 42.18 & & 1.07 & 2.41 \\
\hline Fish fin & & & 9.49 & 14.08 & & 10.54 & & & \\
\hline Fish scales & & 1.89 & 1.73 & & 5.42 & 0.70 & & 2.14 & 0.16 \\
\hline Leaf litter & & 1.89 & 0.19 & & & & & & 0.30 \\
\hline Fine detritus & & & 2.16 & & 5.42 & & & & \\
\hline Woody debris & & & 10.36 & & & & & & \\
\hline Seeds & 0.89 & 0.13 & & & 8.35 & & & & \\
\hline
\end{tabular}


lagoon, $\theta_{j k}=0.11$ for creek, and $\theta_{j k}=0.10$ for the channel (see Appendix 1 for details). Lower values of diet overlap have been reported for other cichlids in Cinaruco River during the dry season (Jepsen et al., 1997). Results showed that during dry season $C$. lugubris consumes a diverse prey items however, adult individuals have seem to have a piscivores diet.

Crenicichla aff. wallacii fed primarily on Crustacea (Cladocera, Copepoda, Ostracoda, and Decapoda) and aquatic insects (mostly Odonata, Ephemeroptera, Trichoptera) followed by fish scales and detritus (Table 2). Aquatic insects were the most important food category for $C$. aff. wallacii throughout the study period. Crenicichla aff. wallacii measuring less than $50 \mathrm{~mm}$ SL from lagoon, creek and channel consumed larger proportions of Crustacea than larger (> $50 \mathrm{~mm} \mathrm{SL}$ ) conspecifics. Diet breadth of $C$. aff. wallacii was low for individuals from all habitat types: $0.17( \pm 0.05)$ for lagoon, $0.05( \pm 0.04)$ for creek, and $0.3( \pm 0.01)$ for the channel. Diet overlap was very low between the two size classes of $C$. lugubris within all three habitats $\left(\theta_{j k}=0.04,0.02\right.$, and 0.03 for lagoon, creek, and channel, respectively). The percentages of empty stomachs were relatively low for both species in all three habitat types throughout the study period (Table 3).

\section{Discussion}

The two Crenicichla species sympatric in the Cinaruco River have very similar morphologies but differ greatly in adult body size. Differences in body size and, to a lesser degree, habitat use seem to be the main factors that influence dietary segregation between these congeners during the dry season.

Crenicichla lugubris larger than $100 \mathrm{~mm}$ SL fed primarily on fishes, whereas individuals less than $100 \mathrm{~mm}$ SL were found to consume mostly aquatic insects. A large proportion of the prey items recovered from $C$. lugubris stomachs were intact. Six fish families were identified, with characids most abundant. Feeding patterns of large C. lugubris agree with those observed by Knöppel (1970), who found that Crenicichla species from the Central Amazon had a carnivorous diet, consisting mostly of fishes but also crustaceans and aquatic insects. Similarly, Lowe-McConnell (1969) found that Crenicichla species from Guyana consumed mostly fishes followed by shrimps. Based on their short guts and small mouth gapes, small Crenicichla species (e.g. C. aff. wallacii, C. britskii, and C. notophthalmus) are expected to have insectivorous feeding habits. Our findings indicated that $C$. aff. wallacii from the Cinaruco River feeds primarily on aquatic insects and crustaceans, accompanied by organic debris that is probably ingested incidentally. Crenicichla geayi, a relatively small species from the western llanos in Venezuela, also was characterized as is a generalized invertebrate feeder (Winemiller et al., 1995). Likewise, Gibran et al. (2001), found that the diet of small C. britskii was dominated by immature aquatic insects (larvae, pupae and nymphs), followed by crustaceans and plant material, and fish remains were found in low amounts. Bethea (2007) found that the dwarf pike cichlid
Table 2. Volumetric percentages of dominant food resource categories consumed by size classes of $C$. aff. wallacii in three habitats of Cinaruco River. Number of stomachs with prey items: Lagoon $(n=42)$, creek $(n=31)$, Channel $(n=25)$.

\begin{tabular}{|c|c|c|c|c|c|}
\hline \multirow{2}{*}{ Items } & \multicolumn{2}{|c|}{ Lagoon } & Creek & \multicolumn{2}{|c|}{ Channel } \\
\hline & $<50 \mathrm{~mm}$ & $>50 \mathrm{~mm}$ & $<50 \mathrm{~mm}>50 \mathrm{~mm}$ & $<50 \mathrm{~mm}$ & $>50 \mathrm{~mm}$ \\
\hline Unident. terr. insect & & & & 0.20 & 3.64 \\
\hline Unident. aq. insect & 1.89 & & & 1.30 & 5.83 \\
\hline Bryozoa & & 0.24 & 0.49 & 0.26 & \\
\hline Cladocera & 0.40 & & 0.29 & 1.69 & \\
\hline Copepoda & 0.28 & & & 1.95 & \\
\hline Ostracoda & 0.09 & & 0.15 & 1.17 & 0.36 \\
\hline Collembolla & & & & 0.65 & \\
\hline Ephemeroptera & 4.04 & 69.03 & 61.73 & & 1.46 \\
\hline Trichoptera & 23.17 & 4.80 & 1.71 & & \\
\hline Naucoridae & 0.47 & 0.08 & & & \\
\hline Odonata & 10.64 & 0.16 & 1.13 & 1.95 & 0.36 \\
\hline Diptera & 10.31 & 0.99 & 3.63 & 8.98 & 10.35 \\
\hline Hirudinea & & & 4.90 & & \\
\hline Nematoda & 0.24 & & 0.98 & 0.00 & 2.92 \\
\hline Hydracarina & 0.21 & 0.03 & & 1.17 & \\
\hline Decapoda & 22.23 & 3.92 & 7.84 & 13.01 & 14.58 \\
\hline Fish scales & 12.77 & 0.78 & & 9.11 & 4.37 \\
\hline Fish eggs & & 0.39 & & & 2.19 \\
\hline Unident. fish & & & & & 11.71 \\
\hline Characidae & & 7.84 & & 19.52 & 14.58 \\
\hline Cichlidae & & & & 0.00 & 36.44 \\
\hline Crenuchidae & & 3.92 & & 27.33 & \\
\hline Hypopomidae & & 7.84 & & & \\
\hline Synbranchidae & & & 7.84 & & \\
\hline Fine detritus & 13.01 & & 9.31 & & 2.92 \\
\hline Algae & 0.24 & 0.01 & & & \\
\hline
\end{tabular}

Table 3. Percentages of empty stomachs recorded for Crenicichla lugubris and Crenicichla aff. wallacii in three habitats for the Cinaruco River during five consecutive months. Number of individuals examined for each month appears in parenthesis.

\begin{tabular}{lccccc}
\hline \multirow{2}{*}{ Habitat } & \multicolumn{5}{c}{ Months } \\
\cline { 2 - 6 } & Dec. & Feb. & Mar. & Apr. & May \\
\hline C. lugubris & & & & & \\
Lagoon & $20.0(65)$ & $8.3(33)$ & $12.7(37)$ & $7.8(31)$ & $2.8(14)$ \\
Channel & $11.3(20)$ & $18.3(18)$ & $12.7(15)$ & $8.4(15)$ & $2.8(3)$ \\
Creek & $27.2(21)$ & $14.6(15)$ & $10.4(14)$ & $12.5(7)$ & 0.0 \\
C. aff. wallacii & & & & & \\
Lagoon & $18.5(20)$ & $20.4(22)$ & $29.6(32)$ & $22.2(24)$ & $9.3(15)$ \\
Channel & $6.4(20)$ & $9.0(17)$ & $7.7(18)$ & $10.3(20)$ & $0.0(10)$ \\
Creek & $35.3(24)$ & $29.4(20)$ & $16.2(11)$ & $14.7(10)$ & $4.4(7)$ \\
\hline
\end{tabular}

Crenicichla notophthalmus feeds mostly on aquatic insect larvae associated with leaf litter. Submerged wood and leaf litter are known to be important habitats for aquatic insects in tropical streams (Ramirez \& Pringle, 1998) and floodplain rivers (Arrington et al., 2005). For example, high densities of collectorgatherer invertebrates in leaf packs in Puerto Rican streams were reported by Ramirez \& Pringle (1998) and Rosemond et al. (1998). Flecker (1992) reported rapid colonization of manipulated substrata by invertebrates in a piedmont river in Venezuela, with from 600 to $>2400$ individuals per $0.25 \mathrm{~m}^{2}$.

Crenicichla lugubris in the Cinaruco River were common near submerged woody debris and rocks, and these habitats probably hold relatively sedentary prey (Arrington \& Winemiller, 2006; Arrington et al., 2005). These structurally 
complex habitats also would provide cover for ambush attacks on highly mobile fishes, such as small characids, that swim nearby. Crenicichla aff. wallacii was primarily associated with leaf litter substrates but sometimes were observed in rocky shoals. High occurrence of pike cichlids, especially $C$. aff. wallacii, in littoral habitats containing woody debris and leaf litter during the dry season was reported by Arrington \& Winemiller (2006) in the Cinaruco River and Layman et al. (in press) in the nearby Caño La Guardia. These habitats hold the highest densities of aquatic insects in the Cinaruco River (Arrington et al., 2005; K. Winemiller (pers. observ.).

Sampling design and methods could have influenced our habitat and dietary data. Our analysis of feeding ecology was limited to one hydrological period, the dry season. Feeding patterns during the high-water period, when many fishes move into the flooded riparian forest and savannas, could differ as a function of variation in availability of resources. For example, Winemiller (1989) documented seasonal dietary shifts among piscivorous fishes a creek in the western llanos. Baited hooks were relatively ineffective for capturing Crenicichla aff. wallacii from rocky substrates. We occasionally observed $C$. aff. wallacii using these habitats, possibly for foraging, refuge, or both. During the onset of the rainy season in May, fishes were able to disperse into the savanna with flood waters. Consequently, May sampling was relatively ineffective in nearly all habitat types. The small number of samples collected during May do not permit us to infer much about dietary patterns during the flood period. Also, collections from creeks yielded fewer pike cichlids than those from lagoons and the main channel, and, as a consequence, diet samples for creeks were small.

Improved knowledge of feeding ecology, life history and habitat requirements of Neotropical fishes is needed for management of natural populations exploited by fisheries as well as the aquarium hobby. We discovered a relatively high degree of dietary and habitat segregation between sympatric pike cichlids, particularly for adult size classes, during the dry season. Ontogenetic dietary shifts of fish species could be driven by seasonal and spatial variation in food availability, especially under the influence of resource competition. Our study was restricted to the dry season, and further research is needed during the rainy season to document annual variation in habitat use, food availability, and diets.

\section{Acknowledgements}

We are grateful to the members of Cinaruco Fishing Club, especially Carol Marzuola and Guillermo Belloso, and Jose Garcia and family for crucial logistic support during our work on Cinaruco River. Donald Taphorn at UNELLEZ provided additional logistical assistance and helped with identification of fishes among stomach contents. Pablo Medina and Wilson Garcia are given special thanks for their help throughout this study. Fish collections were made under scientific permit \# 000074 issued by the Instituto Nacional de Acuicultura y Pesca (INAPESCA) of the Republica Bolivariana de Venezuela.

\section{Literature Cited}

Adite, A. \& K. O. Winemiller. 1997. Ontogenetic, seasonal, and spatial variation in the diet of Heterotis niloticus (Osteoglossiformes: Osteoglossidae) in the So River and Lake Hlan, Benin, West Africa. Environmental Biology of fishes, 73(4): 367-378.

Arrington, D. A., K. O. Winemiller \& C. A. Layman. 2005. Community assembly at the patch scale in a species rich tropical river. Oecologia, 144(1): 157-167.

Arrington, D. A. \& K. O. Winemiller. 2006. Habitat affinity, the seasonal flood pulse, and community assembly in littoral zone of a Neotropical floodplain river. Journal of the North American Benthological Society, 25(1): 126-141.

Barlow, G. W. 2000. The cichlid fishes: nature’s grand experiment in evolution. Cambridge, Perseus Publishing, 317p.

Bethea, F. 2007. A dwarf pike Crenicichla notophthalmus, Regan 1913. Buntbarsche Bulletin, 239: 4-10.

Eschmeyer, W. N. \& R. Fricke. (Eds.). 2009. Catalog of Fishes eletronic version (updated 13 Mar. 2009). http:// research.calacademy.org/ichthyology/catalog/fishcatsearch.html

Flecker, A. 1992. Fish trophic guilds and the structure of a tropical stream: weak direct vs. strong indirect effects. Ecology, 73(3): 927-940.

Gibran, F. Z., K. M. Ferreira \& R. M. Castro. 2001. Diet of Crenicichla britskii (Perciformes: Cichlidae) in a stream of Rio Aguapeí basin, upper Rio Paraná system, Southeastern Brazil. Biota Neotropica, 1(1): 1-5.

Hoeinghaus, D. J., K. O. Winemiller, C. A. Layman, D. A. Arrington \& D. B. Jepsen. 2006. Effects of seasonality and migratory prey on body condition of Cichla species in a tropical floodplain river. Ecology of Freshwater Fish, 15(4): 398-407.

Jepsen, D. B., K. O. Winemiller \& D. C. Taphorn. 1997. Temporal patterns of resource partitioning among Cichla species in a Venezuela blackwater river. Journal of Fish Biology, 51(6): 10851108.

Knöppel, H. 1970. Contribution to the nutrient-ecology of Amazonian rain-forest-streams. Amazoniana, 2(3): 257-352.

Kullander, S. O. 1990. A new species of Crenicichla (Teleostei: Cichlidae) from the Rio Tapajós, Brazil, with comments on interrelationships of small Crenicichline cichlids. Ichthyological Exploration of Freshwaters, 1(1): 85-94.

Kullander, S. O. 1991. Crenicichla phaiospilus and C. percna, two new species of pike cichlids from the Rio Xingu, Brazil. Ichthyological Exploration of Freshwaters, 2(4): 351-360.

Kullander, S. O. 2003. Family Cichlidae. Pp. 605-654. In: Reis, R. E., S. O. Kullander \& C. J. Ferraris Jr. (Eds.). Check list of the freshwater fishes of South and Central America. Porto Alegre, Edipucrs, 729p.

Kullander, S. O. \& C. A. Lucena. 2006. A review of the species of Crenicichla (Teleostei: Cichlidae) from the Atlantic coastal rivers of southeastern Brazil from Bahia to Rio Grande do Sul States, with descriptions of three new species. Neotropical Ichthyology, 4(2): 127-146.

Layman, C. A., C. G. Montaña \& J. E. Allgeier. (in press). Linking community assembly and rates of water level change in river littoral habitats. Aquatic Ecology. 2009.

Layman, C. A. \& K. O. Winemiller. 2004. Sized-based responses of prey to piscivore exclusion in a species rich Neotropical river. Ecology, 85(5): 1311-1320.

Layman, C. A., K. O. Winemiller \& D. A. Arrington. 2005. Body size and trophic position in a diverse tropical food web. Ecology, 
86(9): 2530-2535.

Leibel, W. 1992. The dwarf pikes. Buntbarsche Bulletin, 152: 2529.

Levins, R. 1968. Evolution in changing environments. Princeton, Princeton University Press, 132p.

Lowe-McConnell, R. H. 1969. The cichlid fishes of Guyana, South America, with notes on their ecology and breeding behavior. Zoological Journal of the Linnaean Society, 48(2): 255-302.

Lowe-McConnell, R. H. 1987. Ecological studies in tropical fish community. Cambridge, Cambridge University Press, 371p.

Lucena, C. A. 2007. Two new species of the genus Crenicichla Heckel, 1840 from the upper rio Uruguay drainage (Perciformes: Cichlidae). Neotropical Ichthyology, 5(4): 449-456.

Montaña, C. G., C. A. Layman, D. C. Taphorn \& C. Lasso. 2007. Distribución, alimentación y reproducción de tres especies de pavones Cichla spp. (Perciformes, Cichlidae) en la cuenca baja del río Ventuari, Estado Amazonas, Venezuela. Memoria de la Fundación La Salle de Ciencias Naturales, 165: 83-102.

Montoya, J. V., D. L. Roelke, K. O. Winemiller, J. B. Cotner \& J. A. Sinder. 2006. Hydrological seasonality and benthic algal biomass in a Neotropical floodplain river. Journal of the North American Benthological Society, 2(1): 157-170.

Nikolsky, G. V. 1963. The ecology of fishes. London and New York, Academic Press, 352p.

Pennak, P. 1978. Freshwater invertebrates of the United States. Second edition. New York, Wiley- Interscience Publication, 783p.

Pianka, E. R. 1973. The structure of lizard communities. Annual Review of Ecology and Systematics, 4:53-74.

Ramirez, A. \& C. Pringle. 1998. Structure and production of a benthic insect assemblage in a Neotropical stream. Journal of the North American Benthological Society, 17(4): 443-463.

Rosemond, A. D., C. Pringle \& A. Ramirez. 1998. Macroconsumer effects on insect detritivores and detritus processing in a tropical stream. Freshwater Biology, 39(3): 515-523.

Willis, S. C., K. O. Winemiller \& H. López-Fernández. 2005. Habitat structural complexity and morphological diversity of fish assemblages in a Neotropical floodplain river. Oecologia, 142(2): 284-295.

Winemiller, K. O. 1989. Ontogenetic diet shifts and resource partitioning among piscivorous fishes in the Venezuelan llanos. Environmental Biology of Fishes, 26(3): 177-199.

Winemiller, K. O. 1990. Spatial and temporal variation in tropical fish trophic networks. Ecological Monographs, 60(3): 331-367.

Winemiller, K. O. 1991. Comparative ecology of Serranochromis species (Teleostei: Cichlidae) in the Upper Zambezi River. Journal of Fish Biology, 39: 617-639.

Winemiller, K. O. \& D. B. Jepsen. 1998. Effects of seasonality and fish movement on tropical river food webs. Journal of Fish Biology, 53 (Supplement A): 267-296.

Winemiller, K. O. \& L. C. Kelso-Winemiller. 2003. Food habits of tilapiine cichlids of the Upper Zambezi River and floodplain during the descending phase of the hydrology cycle. Journal of fish Biology, 63:120-128.

Winemiller, K. O., L. C. Kelso-Winemiller \& A. L. Brenkert. 1995. Ecological and morphological diversification in fluvial cichlid fishes. Environmental Biology of Fishes, 44:235-261.

Accepted March 2009

Published June 17, 2009

Appendix 1. Volumetric proportions of major dietary categories consumed by $C$. lugubris and $C$. aff. wallacii in three habitats at Cinaruco River. Calculation of Levins' standardized index of niche breadth (B') and symmetrical niche overlap $\left(\theta_{\mathrm{jk}}\right)$ included only these diet items with volumetric proportions greater than 0.001 .

\begin{tabular}{|c|c|c|c|c|c|c|c|}
\hline & \multicolumn{3}{|c|}{ C. lugubris } & & \multicolumn{3}{|c|}{ C. aff. wallacii } \\
\hline & Lagoon & Creek & Channel & & Lagoon & Creek & Channel \\
\hline Unident. terr. insect & 0.001 & - & - & Unident. aq. insect & - & - & 0.004 \\
\hline Unident. aq. insect & $<0.001$ & $<0.001$ & $<0.001$ & Aquatic insect eggs & 0.007 & - & - \\
\hline Aquatic insect eggs & $<0.001$ & - & - & Bryozoa & $<0.001$ & $<0.001$ & $<0.001$ \\
\hline Coleoptera & $<0.001$ & 0.004 & - & Cladocera & $<0.002$ & $<0.001$ & $<0.001$ \\
\hline Hemiptera & $<0.001$ & 0.005 & - & Copepoda & $<0.001$ & - & $<0.001$ \\
\hline Ephemeroptera & $<0.001$ & $<0.001$ & $<0.001$ & Ephemeroptera & 0.001 & 0.381 & $<0.001$ \\
\hline Naucoridae & $<0.001$ & $<0.001$ & - & Naucoridae & $<0.001$ & - & - \\
\hline Odonata & $<0.001$ & 0.002 & 0.012 & Odonata & - & $<0.001$ & $<0.001$ \\
\hline Diptera & - & $<0.001$ & - & Diptera & 0.001 & 0.001 & 0.010 \\
\hline Oligochaeta & $<0.001$ & - & - & Trichoptera & 0.279 & $<0.001$ & - \\
\hline Hirudinea & $<0.001$ & - & - & Hirudinea & $<0.001$ & 0.002 & - \\
\hline Nematoda & $<0.001$ & $<0.001$ & - & Nematoda & $<0.001$ & $<0.001$ & $<0.001$ \\
\hline Decapoda & 0.020 & 0.004 & 0.002 & Decapoda & 0.001 & 0.006 & 0.019 \\
\hline Fish bone & 0.006 & 0.065 & $<0.001$ & Ostracoda & $<0.004$ & $<0.001$ & $<0.001$ \\
\hline Fish fin & 0.002 & 0.004 & - & Collembolla & - & - & $<0.001$ \\
\hline Fish scales & $<0.001$ & 0.001 & $<0.001$ & Hydracarina & 0.009 & - & $<0.001$ \\
\hline Fish eggs & $<0.001$ & - & - & Fish scales & - & - & 0.005 \\
\hline Unident. fish & 0.031 & 0.002 & 0.015 & Fish eggs & - & - & $<0.001$ \\
\hline Characidae & 0.009 & 0.045 & 0.036 & Unident. fish & $<0.001$ & - & $<0.001$ \\
\hline Cichlidae & 0.012 & 0.007 & 0.021 & Characidae & 0.001 & - & $<0.001$ \\
\hline Doradidae & 0.010 & - & - & Cichlidae & 0.003 & - & 0.030 \\
\hline Anostomidae & 0.005 & - & 0.105 & Crenuchidae & - & - & 0.030 \\
\hline Synbranchidae & 0.002 & - & $<0.001$ & Hypopomidae & 0.001 & - & 0.021 \\
\hline Heptapteridae & $<0.001$ & - & 0.001 & Synbranchidae & 0.003 & 0.006 & - \\
\hline Leaf litter & $<0.001$ & - & $<0.001$ & Fine detritus & $<0.001$ & 0.009 & 0.001 \\
\hline Fine detritus & $<0.001$ & $<0.001$ & - & & & & \\
\hline Woody debris & 0.002 & - & - & & & & \\
\hline Seeds & $<0.001$ & 0.001 & - & & & & \\
\hline $\mathrm{B}^{\prime}$ & 0.33 & 0.22 & 0.16 & $\mathrm{~B}^{\prime}$ & 0.17 & 0.05 & 0.3 \\
\hline$\theta_{\mathrm{jk}}$ & 0.10 & 0.11 & 0.10 & $\theta_{\mathrm{jk}}$ & 0.04 & 0.02 & 0.04 \\
\hline
\end{tabular}

